\title{
A Basic Study of the Automated Generation of Machine Structure (3rd Report, Generation of Skeletal Structure of Motion Transmitting System from Functional Structure)
}

\author{
Masaaki YOKOYAMA and Rae-Kyung PARK
}

\begin{abstract}
As a basic study for the establishment of the methodology for computer aided or automated design of machine structures, this report deals with an algorithm and a computer program for the automated generation of the skeletal structures of the motion transmitting systems of power transmitting or motion transmitting machines, such as machine tools and measuring apparatuses. The motion transmitting systems of the machines are considered as an aggregation of motion transmitting elements, such as gear mechanism, screw driving mechanism and cam mechanism, and their skeletal structures are generated automatically using their functional structures, the algorithm and the application results were explained in the second report of this study. Some results for machine tools are presented, which were generated by the implementation of this computer program.
\end{abstract}

Key Words: Machine Design, CAD, Automated Design, Design Engineering; Machine Structure, Skeletal Structure

\section{1. 絔 言}

機械構造の計算機援用設計方法論を確立するための

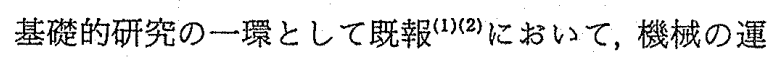
動伝達系の機能構造のグラフ記述法ならびに自動生成 法について述べた。すなわち，機械の運動伝達系を運 動伝達要素の連なりとして把握し, 入力された基本仕 様を满足するように各要素の変換ベクトルを決定し， 必要ならば要素のそう入とその変換べクトルの決定を 自動的に行う技法について述べた。次の課題としては, いかにしてこの機能構造から骨格構造を自動生成する かという問題が残っておうり，その解決が必要である。

本研究に抢ける機械構造の自動生成過程は,

（1）基本仕様の入力から基本グラフの生成

（2）基本グラフから三次元の機能檴造グラフへの 拡張

（3）この機能構造グラフから運動伝達系の骨格構 造の生成

（4）運動伝達系以外の部分の骨格構造の生成

（5）骨格構造への肉付け

\footnotetext{
* 昭和 61 年 11 月 23 日 関西支部第 246 回講演会において講 演, 原稿受付 昭和 61 年 5 月 30 日.

** 正員, 東京工業大学 (②227 横浜市緑区長津田町 4259). **** 学生員, 東京工業大学大学院.
}

の五つの過程から構成されるが, 本報に抢いては（3） の過程の自動化阅する方法論を取扱う。

\section{2. 運動伝達系の骨格構造の生成法}

$2 \cdot 1$ 機能構造と骨格構造本研究において取扱 う機械には機能と形態の二つが不可欠であり,これら は各々第 1 報(1)において説明したような棈造を有して いる。機能構造は運動伝達機能の構造で，まだ「大き さ」の概念が導入されておらず, 形態の大小は問わな い。機能構造が同じであれば，例えば大形旋盤も卓上 小形旋盤もここでは同一のものとみなされる、䒠際の 機械設計には形態の大きさの決定が必須である。しか し, 機能構造から一足跳びに形態構造を生成するのは 難しいので，本研究においてはまず骨格構造を生成し， 次にこの骨格構造に肉付けを行い, 形態構造とする方 式を採用する。

本研究においては，機械の運動伝達系の骨格構造を 次のように定義している。すなわち，機械を構成する 運動伝達要素（以後 $\mathrm{ME}$ と略記する）各部の太さおよ び厚さを捨象し，それら MEの位置とその姿智，ME 間の連がりの仕方をも抽出した機械の構造を骨格構造 と呼称する。ベースのような機械本体はこの場合には MEに含めない。 
2・2 骨格構造の生成法 本報における骨格構造 の生成は全自動的ではなく，設計者と計算機の対話を 一部取り入れた対話方式を採用する。したがって, ME 間の干涉の有無の判定などの技法はこの生成法の中に は含まれていない，骨格構造の良し悪しは設計者が図 形表示装置ならびに出力リストを見ながら判断し，覀 いと判断された部分は計算機との対話により修正する ものとする。

$2 \cdot 2 \cdot 1$ 基本任㥞の入力形成 前報 ${ }^{(2)}$ に扔いて取 扱った三次元の機能構造生成に必要な基本仕様は，前 報と円じく表 1 のように

（1）入力側(Input)の運動の種類 (Motion) と方向 余弦 (Direction)

（2）出力側 (Output) の運動の種類と方向余弦な らびに入力への依存性 (Source)

汃ら構成されている。入力側の運動としては，前報と 同じく回転運動 $R$ を採用する。すなわち，動力源とし て ER タイプの ME を使用する. 入力側の運動の方向 余弦は全体座標系に対する動力源の回転軸の方向余弦 を表す．全体座標系としては， $Z$ 軸を鉛直上方とする 右手直交座標系を使用する。出力側の運動としては 2 系統の運動を用意し，同一系統の出力運動においては 3 つの運動まで重ね合せができる。また，番号の小さ い順に重ね合せるなどは前報と同じである。入力への 依存性はどの動力源により駆動されるかを示し，各々 のINno $I N_{1} \sim I N_{3}$ のいずれかに対応する。

骨格構造の生成のためには，これらの基本仕様に加 えて

（3）動力源の位置

（4）加工架間の種類，大きさ，姿勢ならびにどの 面を加工するか

の情報を与える，往復台などに動力源が取付けられる 場合には位直が可変で決定できないので，特定の位置 に往復台などを固定して動力源の位置を与える。次に 加工空間であるが，機械加工などを行わない測定機械 などに放いては加工堮間を作業空間とでも読みかえる ものとする。加工空間としては図 1 のように，直方体 形と円柱形の加工架間を考えることにし，大きさとし ては図中の諸元を与える。直方体形加工空間において

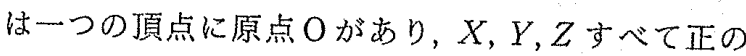
架間にあるものとする。円柱形加工䇥間では端面の円

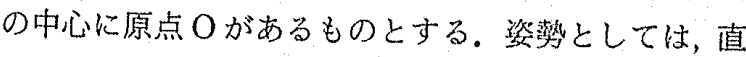
方体形では各面は座標軠に瑟直ですり，丹柱形では軸

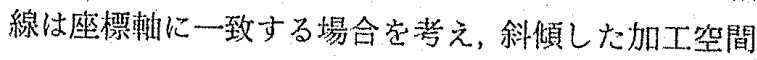
は取扱わない.さらに，どの面急加工寸るかの情報，す な⿰七，直方体栏においては上面か側面加前後面か，
円柱形においては円柱面か端面かの情報を与える。加 工營間は, 被加工物が冒線運動しないときはその大き さ，ある座標軸方向に直線運動するときはその方向に 被加工物を 2 倍した大きさとしている。

$2 \cdot 2 \cdot 2$ 骨格構造の生成法 本報においては, 基 本運動として回転㞄動 $R$, 直線運動 $D$, 往復直線運動 $\bar{D}$ (計算機入出力では $B$ で代用する)の三つを考える。 これらの基本運動を実現し，かつ入力基本運動が $R$

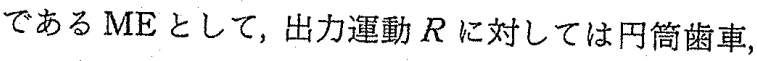
かさ歯車, ウォーム崡車, ベルト駆動機構, 出力運動 $D$ に対してはねじ送り機構, 出力運動 $\bar{D}$ に対しては カム機構, クランクーピストン機構のみを採用してい る。それ辛に、これらの $\mathrm{ME}$ 以外の $\mathrm{ME} の$ 要求され る機械の骨格構造は生成できない。

座標軸としては，機械の基本的な姿勢として長手方 向を全体座標系の $X$ 軸の方向に選ぶ。すなわち, 加工 空間の長手方向を $X$ 軸の方向に選び, 円柱形加工空 間において中心軸を鉛直に立てない場合には中心軸は $X$ 軸の方向に選ぶ。この結果，水平面内にある長い動 力伝達軸, テーブル送り用の長い送りねじなどは基本 的には $X$ 軸に平行になる。

機械の大きさは加工照間の大きさに依存しなければ ならない、すなわち，大きな被加工物を小さな機械で は加工できないし，反対に，小さな被加工物のために 大きな機械を設計するのは不合理である。この場合， 加工空間の大きさにより直接に規定される MEの要 素の大きさ決定には問題はないが，例えば動力源の大

表 1 機能構造生成のための基本仕様

\begin{tabular}{|c|c|c|c|c|c|}
\hline & \multicolumn{2}{|c|}{ Serial No. } & Motion & Direction & Source \\
\hline Input & \multicolumn{2}{|c|}{$\begin{array}{l}I N_{1} \\
I N_{2} \\
I N_{3}\end{array}$} & $\begin{array}{l}R \\
R \\
R\end{array}$ & $\begin{array}{l}\left(1_{1}, m_{1}, n_{1}\right) \\
\left(1_{2}, m_{2}, n_{2}\right) \\
\left(1_{3}, m_{3}, n_{3}\right)\end{array}$ & \\
\hline \multirow{2}{*}{ Output } & A & $\begin{array}{l}1 \\
2 \\
3\end{array}$ & $\begin{array}{l}M_{A 1} \\
M_{A 2} \\
M_{A 3}\end{array}$ & $\begin{array}{l}\left(14, m_{4}, n_{4}\right) \\
\left(15, m_{5}, n_{5}\right) \\
\left(16, m_{6}, n_{6}\right)\end{array}$ & $\begin{array}{l}\text { IN no } \\
I N_{\text {no }} \\
I N_{\text {no }}\end{array}$ \\
\hline & B & $\begin{array}{l}1 \\
2 \\
3\end{array}$ & $\begin{array}{l}M_{B 1} \\
M_{B 2} \\
M_{B 3}\end{array}$ & $\begin{array}{l}\left(17, m_{7}, n_{7}\right) \\
\left(18, m_{8}, n_{8}\right) \\
\left(19, m_{9}, n_{9}\right)\end{array}$ & $\begin{array}{l}\text { IN no } \\
\text { IN no } \\
\text { IN no }\end{array}$ \\
\hline
\end{tabular}
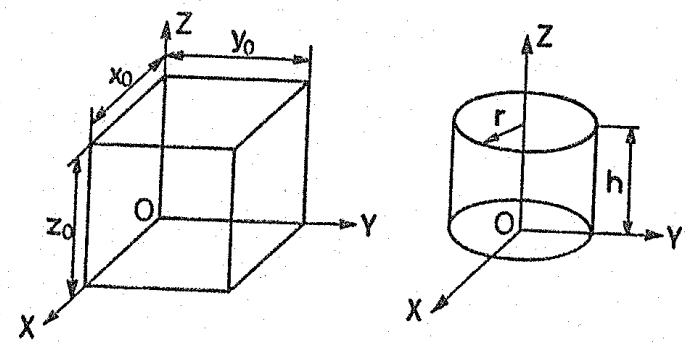

図 1 加工架間の譇元 


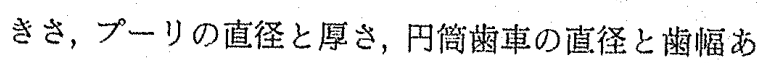

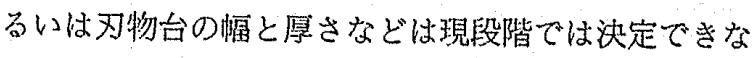
いので, 加工空間の基染寸法に低存して避官決定して いる.加工工具類についても同様である.すなわち, 加 工空間の基準寸法を $L$ とするとき，例元ば，電動機に ついては直径=長さ $=2 L / 7$, プーリとか円筒歯車の ような円板形状要素については直径 $=2 L / 7$, 厚さ = 直径 $/ 4$, 刃物台のような直方体形テーブルについては 幅 $=2 L / 7+10$, 厚さ =幅 $/ 3$, 円板形工具については 直径 $=2 L / 7$ のように一応決めている。これらの寸法 は必要に応じて設計者によって対話的に修正される。 ただし，2L/7は 10 以上，20を越えないものとする。 また，寸法怯無次元としている。基準寸法としては，直 方体形加工架間については空間内部を通る対角線の長 さ，円柱形加工架間については直径を採用している。 骨格構造の生成は次のような過程を経る：

(1) 加工空間の設定,

（2）出力 A 側の基本運動，方向余弦に関して番 号の大きいほうから順次, MEとその大きさ, 位置, 姿勢の決定,

（3）出力 B 側について(2) と同様の決定,

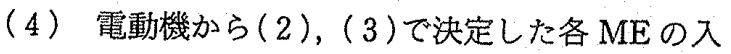
力端までの運動伝達用の歯車, 軸, プーリ, ベルトな どの決定,

（5）対話形式による不都合部分の修正の繰返し，

(6) 骨格構造を構成する $\mathrm{ME}$ 等の各要素の固定 状態, 動力授受の決定と諸元の出力.

以下において，これらの過程に関して詳しく説明し ていく.

最初に; (1)の加工空間の設定であるが,これは入

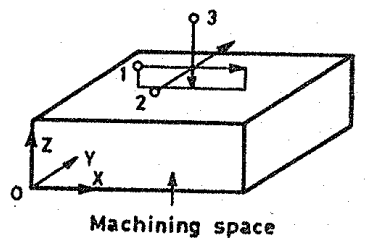

図 2 上平面加工における回転工具の軸方向 あるいは工具の㖶動方向

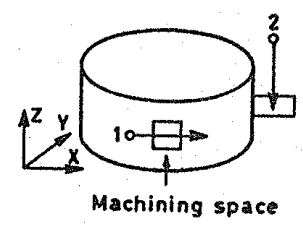

図 3 円柱面加工における回転工具の軸方向 あるいは工具の運動方向

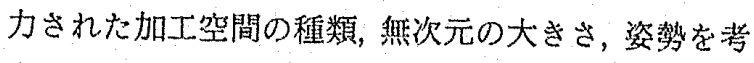
憵して原点周りに設定する。

次に，(2)の加工工具の取付けられる出力 $\mathrm{A}$ 側の MEの種類，大きさ等の決定について考える。ここで は表 1 の基本運墈 $M_{A 1} \sim M_{A 3}$ 苍直接出力する $\mathrm{ME} の$ みについて取扱い，それ以外の造動伝達用の $\mathrm{ME}$ 等に ついては (4)において取扱う。決定は番号の大きいほ うから順次行う。MEの種類としては, 前述のように 本報に格いては RR 要素としては歯車機構, ベルト駆

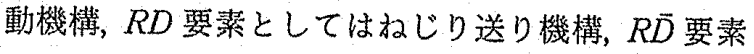
としてはカム機棈，クランクーピストン機樮（回転円板 ーピストン機棈で代用)のみを採用しているので, 表 1 の基本運動 $M_{A 1} \sim M_{A 3}$ が $D$ の場合は自動的にねじ送

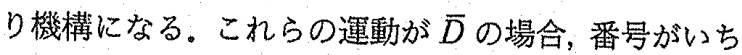
ばん大きいときは回転円板ーピストン機楎，それ以外 のときは力ム機㘪を採用するように現段階のアルゴリ ズムではなっている。さらに，これらの基本運動が $R$ の場合, 番号がいちばん大きく，かつ単独の電動機て 駆動されるときはベルト駆動機構, それ以外のときは 畨車機棈を採用する。告た，加工工具の運動が $M_{A 1}$ $+R+\bar{D}$ タイプの場合, 加工面が円柱面, $R$ と $\bar{D}$ と 円柱の回転軸が平行, かつ被加工物の回転と同一の電 動機で駆動されるときはこの $R$ を出力する $\mathrm{ME}$ はウ オーム宷車機樯とする。この場合, 被加工物の回転運 動を出力する $\mathrm{ME}$ もウォーム歯車機構を採用する。各

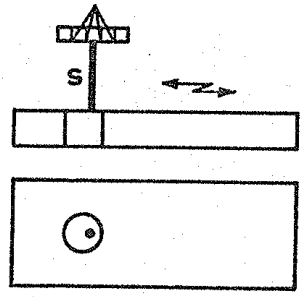

図 4 偏心力ム機粠

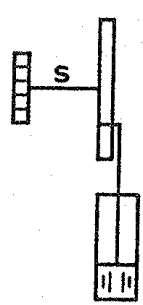

図 5 回転円板一 ピストン機構 (a)

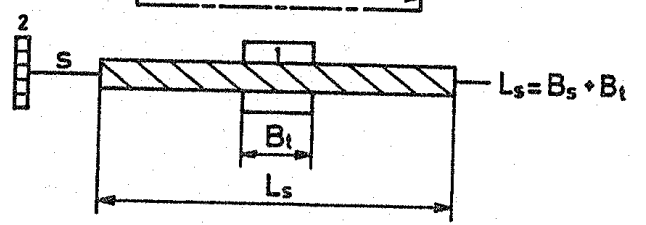

(b)

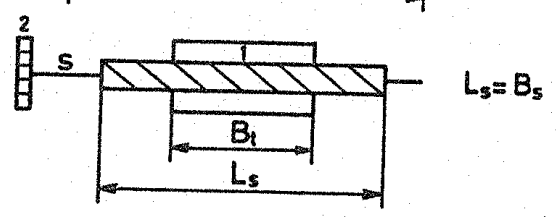

図 6 ねじ送り機棈とねじの長さ 
$\mathrm{ME}$ の姿勢は，その出力軸の方向余弦が表 1 の $M_{A 1} \sim$ $M_{A B}$ の対応する基本運動の方向余弦に一致するように 決め，またその入力軸は座標軸に平行になるように決 定する。各 MEの位置と大きさは番号の大きいほうか ら順次決めていかなければならない，加工工具の取付 けられる番号のいちばん大きい MEに関しては, どの 面を加工するかの情報抢よびその基本運動の種類と軸 方向あるいは運動方向を考慮して決定される. 図 2 お よび図 3 に, 方向が座標軸に平行な場合の回転工具の 軸方向あるいは加工工具の運動方向の例を図示してい る。図 2 に扔いて, 方向 1，2 は円筒フライス, 平面研 削, 形削りなどの加工に対応し, 方向 3 は正面フライ スドリルなどの加工に対応する。また，図 3 では方向 1 は円筒藏車のホブ切り, 方向 2 は円筒研削, 歯車形 削りなどの加工に対応する，加工面の中央の点から， 加工工具の直径あるいは長さに対応した規定距離だけ シフトとしたO印を付けた点を起点として $\mathrm{ME}$ を取 付ける。例えば，䨑車機構の場合にはこの点から方向

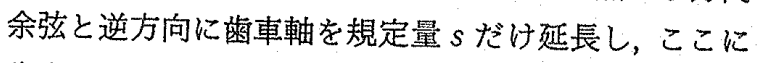
歯車を取付ける。この規定量 $s$ 恔 4 〜図 7 における $s$ につても共通で, $s=40$ としており, 必要に応じ て後程各々の場合に修正する。 $R \bar{D}$ 要素として採用し ている図 4 の偏心カムの偏心量, 図 5 の回転円板-ピ ストン機構の回転円板の大きさ, シリンダの長さは必 要なストロークの大きさに依存する。加工工具の運動 が二つの直交する $D_{1}$ と $D_{2}$ の重ね合せ $D_{1}+D_{2}$ のと き, 二つの直方体形テーブルは重社合され， $D_{2}$ のテー ブルの大きさは前述の規定幅を一辺とする正方形に選 ぶが, $D_{1}$ のテーブルの長さは $D_{2}$ の送りねじの長さに 足りるものとしなければならない。直径あるいは幅が 100 以上の加工空間の上平面の加工の場合には門型構 造を採用することにしており，上下方向移動テーブル は対称位置に配置される 2 本の送りねじにより駆動さ れる。図6に送り机じの長さの決め方を示す，(a)は 被加工物が移動しない場合，(b)は移動する場合に対 応する。

(3)の被加工物の取付けられる出力 B 側の ME の 種類，大きさ等の決定について考える.（2）の場合と 同様に, 表 1 の基本運動 $M_{B 1} \sim M_{B 3}$ を直接出力する MEのみについて取扱う。決定は番号の大きいほうか ら順次行う。基本運動の重㸚合せについて考えると， 直方体形加工堮間においては $D$ 運動の重站合せ，す なわち $D_{1}+D_{2}+D_{3}$ のタイプの出力運動で胟䡃され， 円柱形加工空間に扎ては $D$ 運動に $R$ 運動が重ね合

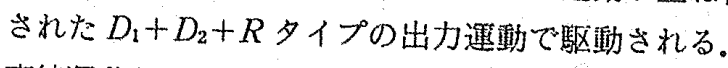
直線運動あるいは回転運動するテーブルの重的合せに
なり，その運動方向および回転軸の方向は表 1 の方向 余弦に基づいて決定される。どちらの場合も $M_{B 3}$ 運動 するテーブルの大きさはその上にのせられる被加工物 の大きさに依存する。 $D$ 運動出力はすべてねじ送り機 構により出力されるが, $R$ 運動出力, すなわち回転す る円柱形加工空間の駆動は図 7 のような 2 種類の駆動 法による、円筒菡車のホブ切り，歯車形削りの場合は （b）を使用する.（b）においては回転テーブルに菡切 りしてウォーム歯車機構を形成させ, 長さ40の歯車 軸はそれが水平面内にあるとき惊 $X$ 軸に平行に配置 する。

続いて，(4)の電動機から（2)，(3)で決定した各 MEの入力端までの運動伝達用の苳車, 軸, プーリ, ベルトなどの決定について考える。出力 $\mathrm{A}$ 側, B 側も 同じ電動機で駆動されると仮定するとき，最初に電動 機からの運動伝達系が設定されるのは, 出力 $\mathrm{A}$ 側の $M_{A 1}$ を出力する $\mathrm{ME}$ の入力端と出力 $\mathrm{B}$ 側の $M_{B 1}$ を出 力する $\mathrm{ME}$ の力端のうち電動機までの距離が短い ほうである.ここで，MEの入力端とは，図4～図 7 に 例示するように霜車が取付けられる長さ 40 の運動伝 達軸の軸端を意味している。電動機までの距離は, こ の二つの入力端から，電動機の端面から垂直に突出た 長さ 20 の運動伝達軸の軸端 (電動機の出力端) までの 距離である。図 8 に電動機からの運動伝達系の設定方 法を示す。この運動伝達系の最初の ME は必ずベルト

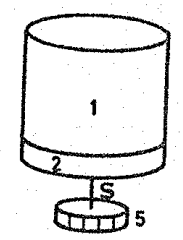

(a)

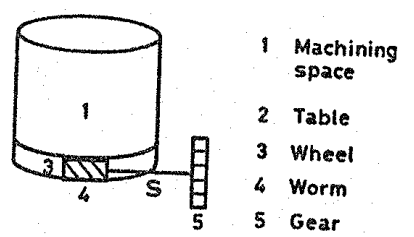

(b)
図 7 、回転する円柱形加工空間の駆動法

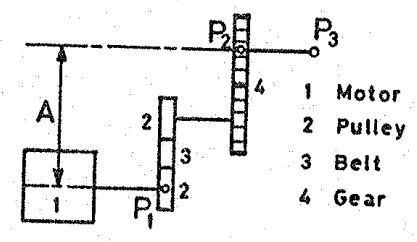

図 8，電動機から他の軸への運動伝達系

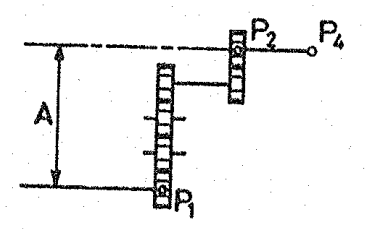

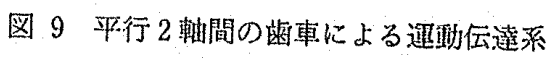


駆動機標とする。以下に㭁いて出力 $\mathrm{A}$ 側が採択された と仮定して説明する。图 8 に打いて $P_{1}$ は電動機の出力 端， $P_{3}$ は $M_{A 1}$ を出力する $\mathrm{ME}$ の入力端とする。 $P_{2}$ は 電動機の出力朝と平行に $\mathrm{P}_{3}$ 少ら距離 40 の点とする。. $\mathrm{P}_{3}$ に战いて $\mathrm{ME}$ の入力軸と線分 $\mathrm{P}_{2} \mathrm{P}_{3}$ が平行のとき $\mathrm{P}_{2}$ は $\mathrm{P}_{3}$ に一致させる。平行でないときは $\mathrm{P}_{3}$ に扮い てかさ歯車が採用される。このようにして図 8 に示す ように， $\mathrm{P}_{2}$ において水平面内に規定の大きさの一刘の 円筒歯車対を設定し，また $\mathrm{P}_{1}$ に扔いて規定の大きさ

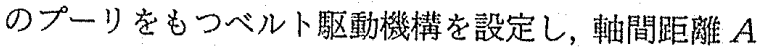
に対応してべルト長さを調整して運動伝達系を設定す る. 次に図 9 に基づいて，出力 $\mathrm{B}$ 側の $M_{B 1}$ を出力する $\mathrm{ME}$ [これを $\mathrm{ME}\left(M_{B 1}\right)$ と表す］までの運動伝達系の 設定について説明する．ME $\left(M_{A_{1}}\right)$ の入力軸上におい て $\mathrm{P}_{3}$ から規定量離机た点 $\mathrm{P}_{4}$ を設け, この点から $\mathrm{ME}$ $\left(M_{B 1}\right)$ の入力軸に平行に 40 離れた点 $\mathrm{P}_{2}$ を設定し; 入 力端 $\mathrm{P}_{1}$ の間に図 9 のような円筒歯車列を設定する。歯 車列は 2 軸を結ぶ直線上に配置し, $\mathrm{P}_{2}$ 側は一対, $\mathrm{P}_{1}$ 側 は軸間距離 $A$ に応じて変化する. $\mathrm{ME}\left(M_{A i+1}\right), \mathrm{ME}$ $\left(M_{B i+1}\right)$ までの運動伝達系は, $\mathrm{ME}\left(M_{A i}\right), \mathrm{ME}\left(M_{B i}\right)$ の入力軸上に $\mathrm{P}_{4}$ に相当する点, およびこの点を基準 として $P_{2}$ に相当する点を設定し, 図 9 と同様に設定 する.

以上の方式に従って骨格構造を生成しても必ずしも 完全なものは得られず, $\mathrm{ME}$ 間の干涉, ME と加工空 間の干渉など不都合が生じる。不都合部分の修正は表 示図形および出力リストを見ながら対話形式に行う. 現在のプログラムで修正できる構造諸元は，運動伝達 軸の長さ, 一対の齒車のかみ合い位置, 運動伝達朝の 分岐の位置などである。

前報においては機能構造を嚾接行列によって表現 し, ME 間の運動伝達の有無, ME の入出力軸が他の $\mathrm{ME}$ の入出力軸に固定されているのか相対運動が許さ れているのかなどの関係を与えた。しかし，骨格構造 においては MEの数も多くなり,また運動妘達軸など $\mathrm{ME}$ 以外のものも含まれてくるばかりでなく，大きさ の概念, 位置の概念も入ってくるので，隣接行列のみ では表現しきれない。そこで，隣接行列は前報の基本 行列，準基本行列の段階にとどめておいて，骨格構造 を表現するために MEを単体の要素にまで分割する。 そして, 骨格構造を軸状, 円板状, 直方体状などの単 体の集合として把握し，それら単体の位置，大きさ， 方向, 固定か否か, 運動伝達などの情報の総合として 表現する。単体間の固定加否か，運動伝達の関係は基 本行列, 準基本行列を参照して個別に決定する。

\section{3. 運動伝達系の骨格構造の生成例}

$3 \cdot 1$ 制限慗項のまとめ 前章において概略説明 した骨格權造の生成法に基づいて FORTRANによ る骨格構造生成プログラムを作成した。本プログラム は約 3000 行のプログラムであり，その邀用の際の制 限事項は前報の五つの制限事㖽に加之て, 前述のよう $に, R R$ 要素, $R D$ 要㨞, $R \bar{D}$ 要素に対して少数の限定 した $\mathrm{ME} し か$ 用意されていないので，それらの $\mathrm{ME}$ 以外の MEが要求される骨格構造が生成できない点 である。

$3 \cdot 2$ 基本仕様の入力方式 機械の基本仕様は対 話形式で入力する.図 10 亿菊車形削り盤の基本仕様の 入力方式を示すが, 本プログラムの使用者は下線を施 した数値，記号のみを入力すればよい。

3・3 骨格構造の生成例 骨格構造生成例として 旋盤と歯車形削り监を取りあげる。

旋盤の基本仕椂として，円柱形加工架間（直径 70, 長さ $120, X$ 軸平行, 円柱面加工), 電動機 1 [方向余 弦 $(1,0,0)$, 位置 $(-120,50,-20)]$, 出力 $\mathrm{A}\left(D_{1}\right.$ $\left.+D_{2}\right)$, 出力 $\mathrm{B}(R), D_{1}$ [方向余弦 $(1,0,0)$, 電動 機 1 で駆動], $D_{2}$ [方向余弦 $(0,1 ， 0)$, 電動機 1 で 駆動], $R$ [方向余弦 $(1,0,0)$, 電動機 1 で駆動]

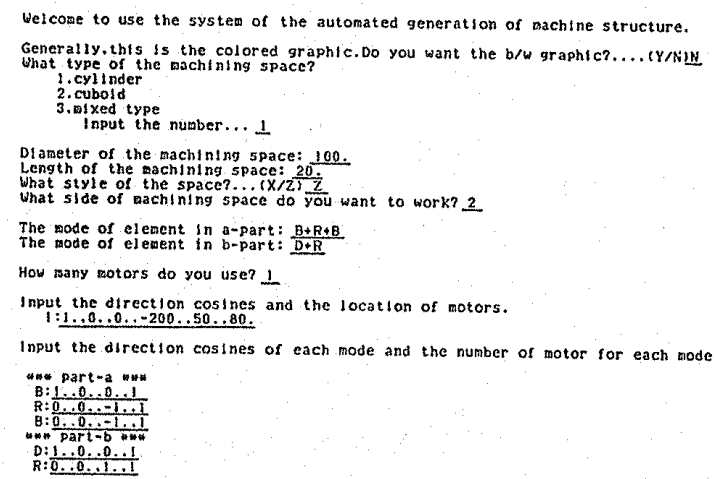

図 10 機械の基本仕様の入力形式

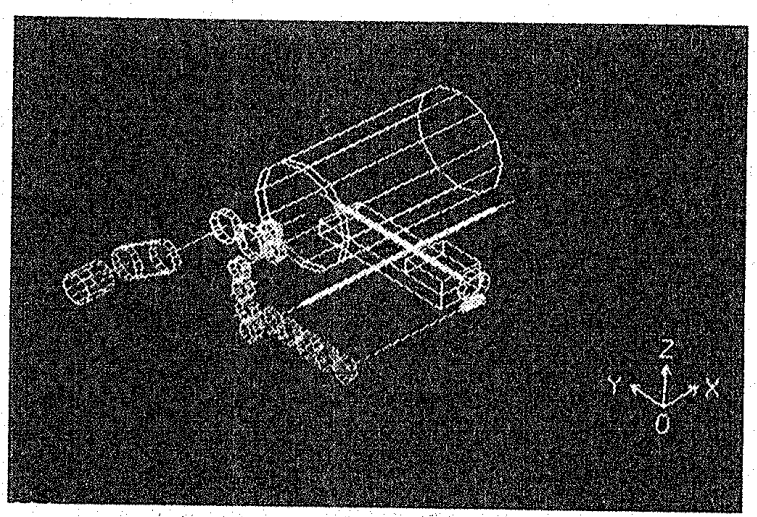

図 11 旋盤の骨格構造の表示結果 
*** SPECIFICATIONS OF ELDIENTS *W*

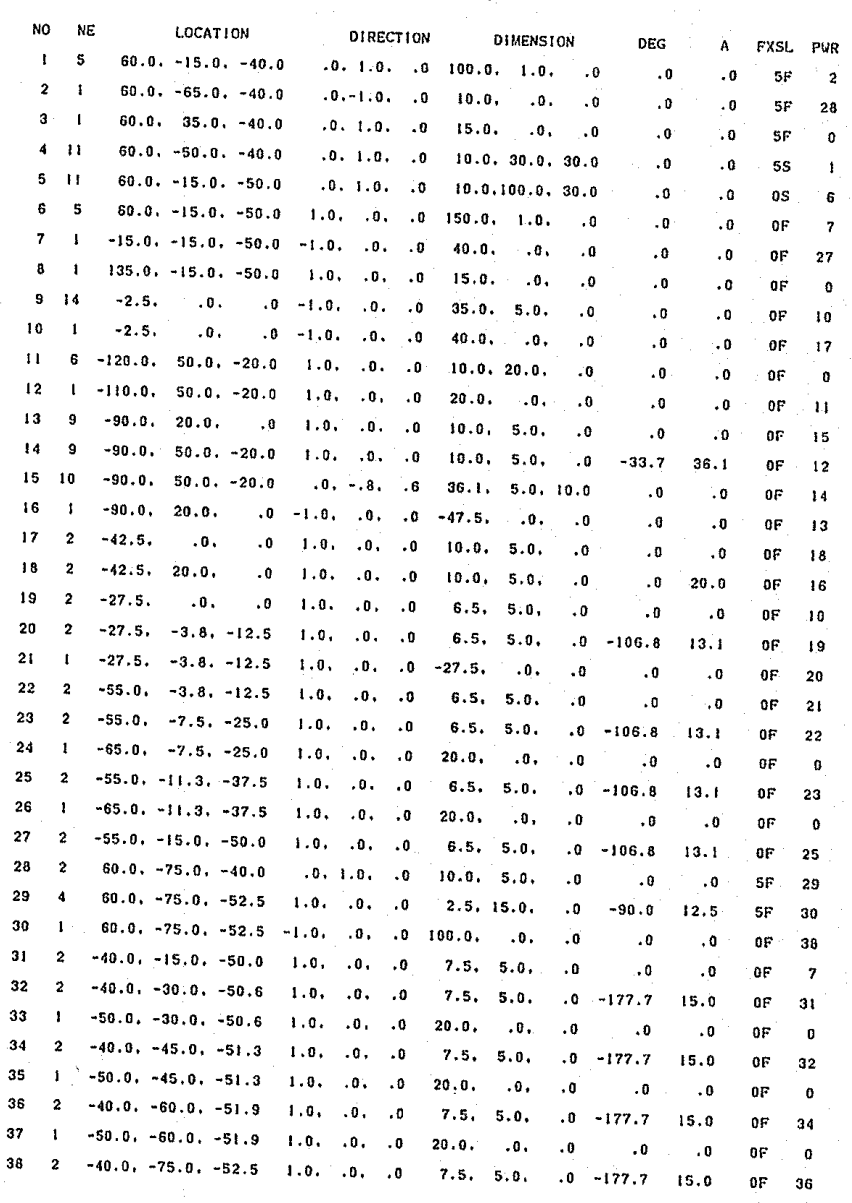

図 12 要素諸元の出力リスト

与える。この仕様を本プログラムによって処理すると 図 11 の骨格構造の図形表示結果, 図 12 の要素諸元の リストが得られる。図12のリストに扔いて, 左より要 素の番号, 種類, 位置, 方向余弦, 大きさ, 加み合い位 置の角度, 軸間距離, 固定加滑動か, 動力をもらう要 素の番号を示す。要素の種類は 1 : 軸, 2 : 円筒苜車, $4:$ : ーム, 5 : 送りねじ, 6 : 電動機, $9:$ オー リ, $10 ：$ ベルト, $11:$ 直方体テーブル, $14:$ 円形テー ブルを示す。位圆は軸以外は重心の位置を示し，軸は スタート位置を示す。このために後述の軸の長さに負 号がつく場合がある。大きさは軸：(長さ，*，*),円 柱形要素：(半径, 幅，*), 送り权じ：（長さ，太さ， *), テーブル：(厚み, 長さ, 幅), ベルト：(軸間距 離, 愊, プーリ半径〉のように春す、固定か滑動かの FXSLにおいて，最初の数字は固定される要素を表 し, 次の記号は固定 (F) 汃滑動 (S) かを表し，0は機 械本体学表す。動力を当的要素の翻号を示与 PWR において，0は動力をもらう要䕀のない電動機むるい 弾なる支持の軸を示している。

齿車形削り盤の基本訨様として図 10 の仕様を与え
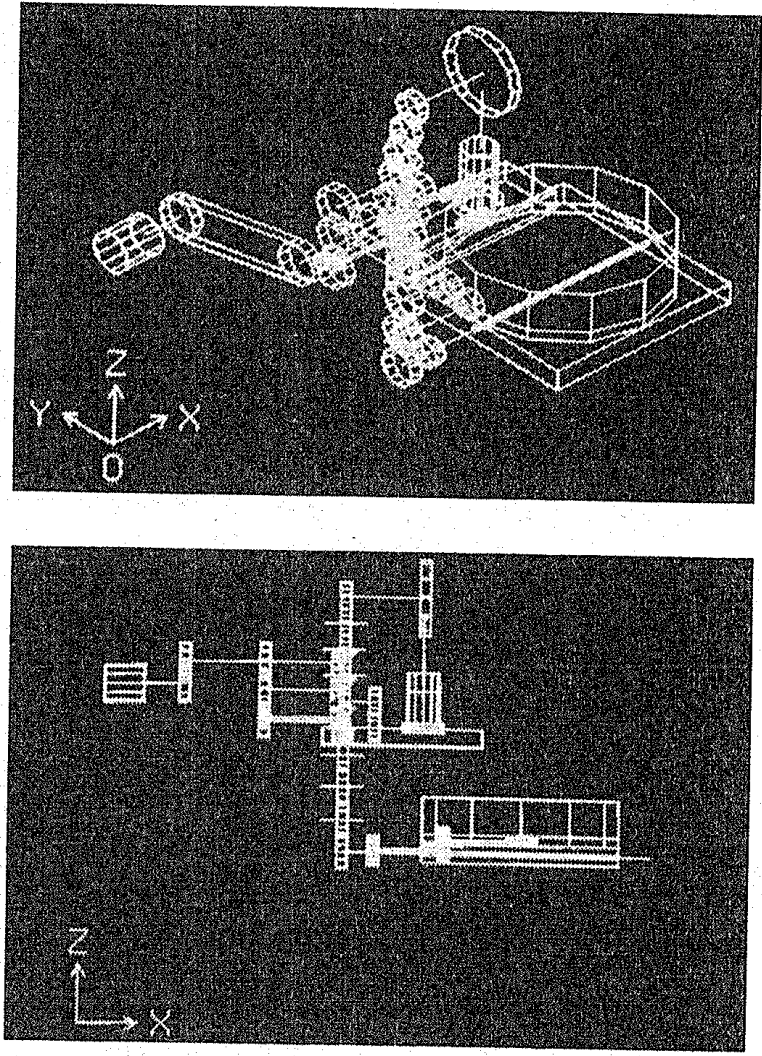

図 13 菡車形削り盤の骨格㮔造の表示結果 (修正前)
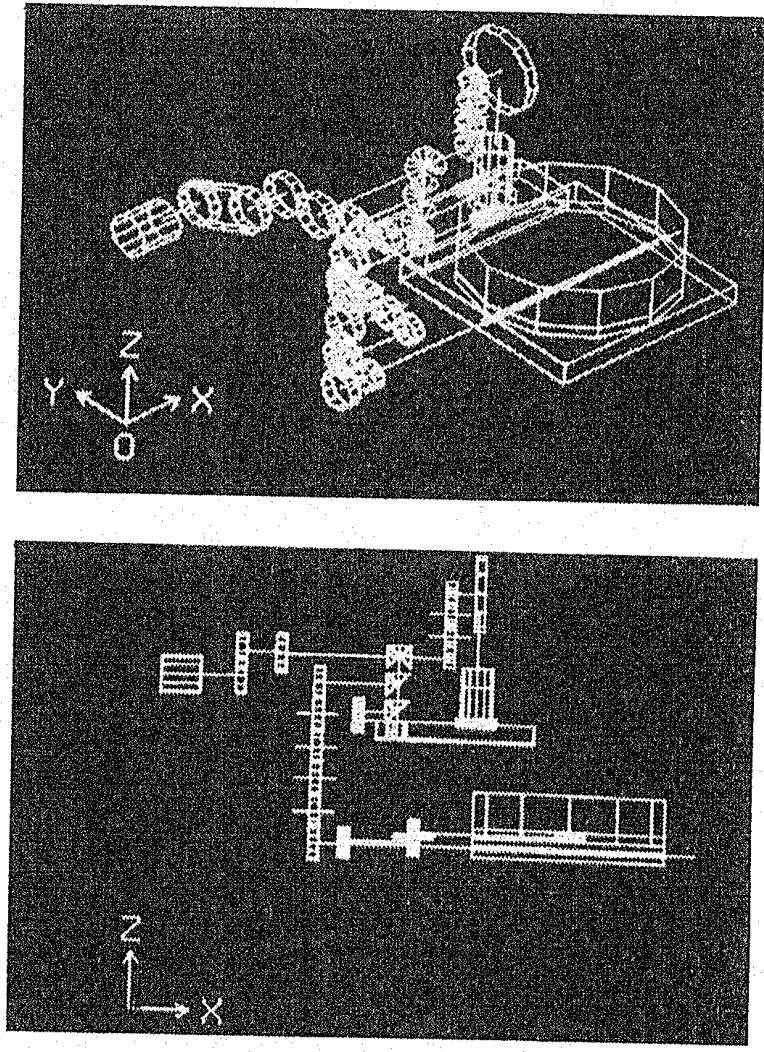

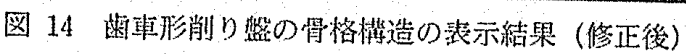


る.出力 $\mathrm{A}$ 側に加工工具, 出力 B 側に被加工物を取付 ける。この仕様を本プログラムによって処理すると， 最初は図 13 のような不都合な部分を含んだ骨格構造 の図形表示結果が得られる。次に，不都合部分等の修 正を施すと図 14 の骨格構造の図形表示結果が得られ る. 要装諸元の出力リストは長くなるのでここでは省 略させていただく、図 13 の不都合部分等の修正前の表 示図形を見るに，加工空間駆動用の 4 個の内筒菊莗の 列は加工空間内に侵入しており，また，出力 $\mathrm{A}$ 側の最

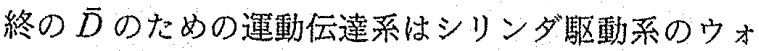
一ム軸から分岐している。これらの 2 点を修正すれば 図 14 の骨格構造の図形表示結果が得られる。

以上に扔いて，旋盤と歯車形削り盤の骨格構造の生 成結果について説明したが，他の機械の場合と同様に 期待どおりの骨格構造が生成され，作成したプログラ
ムの有効性に確信先持つに至った。

\section{4. 結 需}

機械棈造の計算機援用設計方法論の確立のための研 究の一環として，機棫の骨格構造の自動生成を取り方 げ，てのための技法を開発した。また，この技法に基づ いて対話形式の計算機プログラムを作成し，実際の機 械の骨格桙造の生成に適用し，技法と計算機プログラ 么の有効性を確かめた。

終わりに，日頃有益な助言とご協力をいただいてい る本学大学院 林 国一教授に㕌く謝意を表す。

$$
\text { 文献 }
$$

（1）横山・ほか 2名, 機論, 51-465, C (昭 60), 1152.

（2）横山・滛加 2 名，機諭，52-473，C (昭 61)， 417. 